\title{
Trace gas measurements from infrared satellite for chemistry and climate applications
}

\author{
C. Clerbaux ${ }^{1}$, J. Hadji-Lazaro ${ }^{1}$, S. Turquety ${ }^{1}$, G. Mégie $^{1}$, and P.-F. Coheur ${ }^{2}$ \\ ${ }^{1}$ Service d'Aéronomie, Institut Pierre-Simon Laplace, Paris, France \\ ${ }^{2}$ Laboratoire de Chimie Physique Moléculaire, Université Libre de Bruxelles, Belgium \\ Received: 3 February 2003 - Published in Atmos. Chem. Phys. Discuss.: 15 April 2003 \\ Revised: 24 August 2003 - Accepted: 17 September 2003 - Published: 25 September 2003
}

\begin{abstract}
Space-borne thermal infrared instruments working in the nadir geometry are providing spectroscopic measurements of species that impact on the chemical composition of the atmosphere and on the climate forcing: $\mathrm{H}_{2} \mathrm{O}, \mathrm{CO}_{2}$, $\mathrm{N}_{2} \mathrm{O}, \mathrm{CH}_{4}, \mathrm{CFCs}, \mathrm{O}_{3}$, and $\mathrm{CO}$. The atmospheric abundances obtained from the analysis of IMG/ADEOS measurements are discussed in order to demonstrate the potential scientific return to be expected from future missions using advanced infrared nadir sounders. Some strengths and limitations of passive infrared remote sensing from space are illustrated.
\end{abstract}

\section{Introduction}

During the past decade, trace gas abundances in the troposphere were obtained from sparsely distributed measurement sites, and observations were mostly confined to the surface. The advent of downward looking instruments to probe the troposphere from polar-orbiting satellites has dramatically increased our ability to access the impact of human activities on the chemical composition of the atmosphere and on the climate changes.

Three concepts of passive remote sensors have now demonstrated their ability to provide tropospheric sounding measurements: correlation radiometers (e.g. MOPITT), UV-visible radiometers using the reflected/scattered solar radiation (e.g. GOME and sucessors SCIAMACHY, OMI, GOME2), and infrared spectrometers using the Earth's thermal emission as a source (e.g. IMG and follow on AIRS, TES, IASI). All these instrument acronyms are detailed in Table 3, along with some information on the satellite and the launch date. The design and technical specifications (spectral range, spectral resolution, footprint on the ground, scanning

Correspondence to: C. Clerbaux

(ccl@aero.jussieu.fr) mode) of each instrument is optimized as a function of the scientific objectives to be achieved during the mission.

The Interferometric Monitor for Greenhouse gases (IMG) (Kobayashi et al., 1999a) launched aboard ADEOS in August 1996 was the first high resolution nadir infrared instrument allowing the simultaneous measurement from space of a series of trace gases: $\mathrm{H}_{2} \mathrm{O}, \mathrm{CO}_{2}, \mathrm{~N}_{2} \mathrm{O}, \mathrm{CH}_{4}, \mathrm{CFCs}, \mathrm{O}_{3}$, and CO. Unfortunately, in June 1997, the ADEOS satellite ceased to collect and transmit data due to a power failure in its solar panel. However, the measurements performed during 9 months provide a unique opportunity to demonstrate the potential scientific return to be expected from scheduled missions, as the Infrared Atmospheric Sounding Interferometer (IASI) that will fly onboard the METOP suite of satellites during 2005-2020.

In the framework of the IASI mission, we have developed processing tools to analyze Level 1 data (geolocated radiance spectra) to retrieve Level 2 products (trace gas contents at the measurement locations) and enhanced Level 3 products (global distributions). This paper describes the results we have obtained so far by analyzing the IMG measurements using the IASI trace gas algorithm package. Studies already detailed in previous publications are only reported, whereas more recent results are presented here. Scientific work related to IASI or IMG studies performed by other research groups is also reported.

The outline of the paper is as follow: Sect. 2 describes the IMG instrument and measurements, Sect. 3 details the trace gas and temperature retrievals and discusses associated uncertainties in term of atmospheric observation requirements. Direct and indirect validation means are described in Sect. 4. Section 5 concludes the study and provides some perspectives for future instrument platforms. 
Table 1. IMG Level $1 \mathrm{C}$ analyzed data

\begin{tabular}{lcc}
\hline Period & Number of spectra & Cloud-free spectra \\
\hline 26-28 December 1996 & 5178 & 3292 \\
25-28 January 1997 & 7128 & 4499 \\
01-10 April 1997 & 20736 & 12741 \\
16-19 June 1997 & 6192 & 3690 \\
\hline
\end{tabular}

\section{The IMG instrument and data}

The IMG instrument was developed by the Japan Resources Observation System Organization (JAROS) for the Ministry of International Trade and Industry (MITI) and was launched as part of the ADEOS payload. ADEOS was a sunsynchronous (equator local crossing time at descending node at 10:30 a.m.), ground track repeat, polar-orbiting satellite. The instrument performed a global coverage of the Earth, making $14 \frac{1}{4}$ orbits per day with series of six successive measurements separated by $86 \mathrm{~km}$ (every $10 \mathrm{~s}$ ) along the track, followed by the observation of deep space and of an internal blackbody for calibration purposes. Due to the huge data flow rate, the operational mode of IMG was set to 4 days operation/10 days halt alternation, except for one specific period from 1 to 10 April 1997 for which 10 consecutive days are available.

IMG was a nadir-viewing Fourier transform interferometer that recorded the thermal emission of the Earth-atmosphere system between 600 and $3030 \mathrm{~cm}^{-1}$, with a maximum optical path difference (MOPD) of $10 \mathrm{~cm}$ (Kobayashi et al., 1999a). The footprint on the ground was $8 \mathrm{~km} \times 8 \mathrm{~km}$, in three spectral bands (band 1 from 2387 to $3030 \mathrm{~cm}^{-1}$, band 2 from 2000 to $2500 \mathrm{~cm}^{-1}$, and band 3 from 600 to $2000 \mathrm{~cm}^{-1}$ ), corresponding to three different detectors and three geographically adjacent footprints. Level $1 \mathrm{C}$ radiance spectra, distributed by IMGDIS/ERSDAC, were unapodized and are characterized by a spectral resolution (defined as Full Width at Half Maximum-FWHM) of $0.07 \mathrm{~cm}^{-1}$ in band 2, and $0.11 \mathrm{~cm}^{-1}$ in band 3. Due to the high level of noise associated with band 1 , the results presented in this paper were limited to the use of band 2 and band 3 .

Each atmospheric radiance spectrum is provided with quality flags, on three separate criteria: quality of the interferogram, quality of the alignment, and phase difference (Kobayashi et al., 1999b). A preliminary selection was performed by IMGDIS before distribution to remove all bad quality flagged data. In addition, as the presence of clouds in the field-of-view can adversely affect retrieved concentration distributions, we developed a cloud filter method using skin temperature. It was tested along with the clouds products provided by the POLDER instrument that flew onboard the same satellite. Details of the method may be found in Hadji-Lazaro et al. (2001). Another cloud-filtering method for IMG using OCTS/ADEOS data is described in Masiello et al. (2003). Among the available Level 1C radiance data, we selected four good-quality measurements periods (see Table 1) that were cloud-filtered for further analysis of trace gases contents. Most of the illustrations provided in this paper use the April period for which 10 consecutive days were available.

\section{Remote sensing measurements}

\subsection{Atmospheric spectra (Level 1)}

From the high resolution atmospheric spectra provided by the IMG instrument it is possible to retrieve information on many geophysical variables. Pioneering studies were undertaken to assess the extent to which atmospheric temperature and concentrations of infrared-absorbing molecules could be retrieved with useful accuracy from upwelling spectral radiances (e.g. Chahine et al., 1970; Smith et al., 1991; Wetzel et al., 1995). Concentration measurements based on IR Fourier transform spectroscopy were reported for groundbased (e. g. De Mazière et al., 1999), balloon-borne (e. g. Té et al., 2002) and airborne experiments (e. g. Worden et al., 1997), as well as for limb sounders (Abrams et al., 1996) and futur nadir sounders like TES (Clough et al., 1995; Luo et al., 2002) and IASI (Prunet et al., 1998; Clerbaux et al., 1998; Aires et al., 2002b).

To be detected from space, a molecule needs first to have a spectral signature within the instrumental spectral range, and second to be present with a sufficient atmospheric concentration. Figure 1 provides an IMG absorption spectrum (in transmittance units) representative of a non-polluted area over Pacific Ocean, along with the detailed individual absorption contribution of a set of molecules simulated using a line-by-line forward transfer model parametrized for IMG.

It can be seen that the main absorption features in the 600$2500 \mathrm{~cm}^{-1}$ spectral range are associated with rotational transition lines related to the fundamental vibrational bands of $\mathrm{H}_{2} \mathrm{O}, \mathrm{CO}_{2}, \mathrm{O}_{3}, \mathrm{~N}_{2} \mathrm{O}, \mathrm{CH}_{4}$, and $\mathrm{CO}$. All these species combine intense absorption lines in this spectral range with high levels of atmospheric concentration. Weaker absorption contributions (transmittance lower than 10\%) are due to the presence of CFC11, CFC12, $\mathrm{HCF} 22, \mathrm{HNO}_{3}, \mathrm{OCS}, \mathrm{NO}$ and $\mathrm{NO}_{2}$. All these molecules either have weak infrared absorptions, or have currently low atmospheric mixing ratios.

\subsection{Trace gases and temperature retrieval (Level 2)}

Inversion of geophysical parameters from remotely sensed observations is well known to be an ill-posed problem, as no unique solution exists. A variety of methods have been developed to retrieve temperature and concentration profiles from the spectra measured by remote sounders. A large body of literature is available on the subject, and the most widely used approaches in atmospheric remote sensing are described 

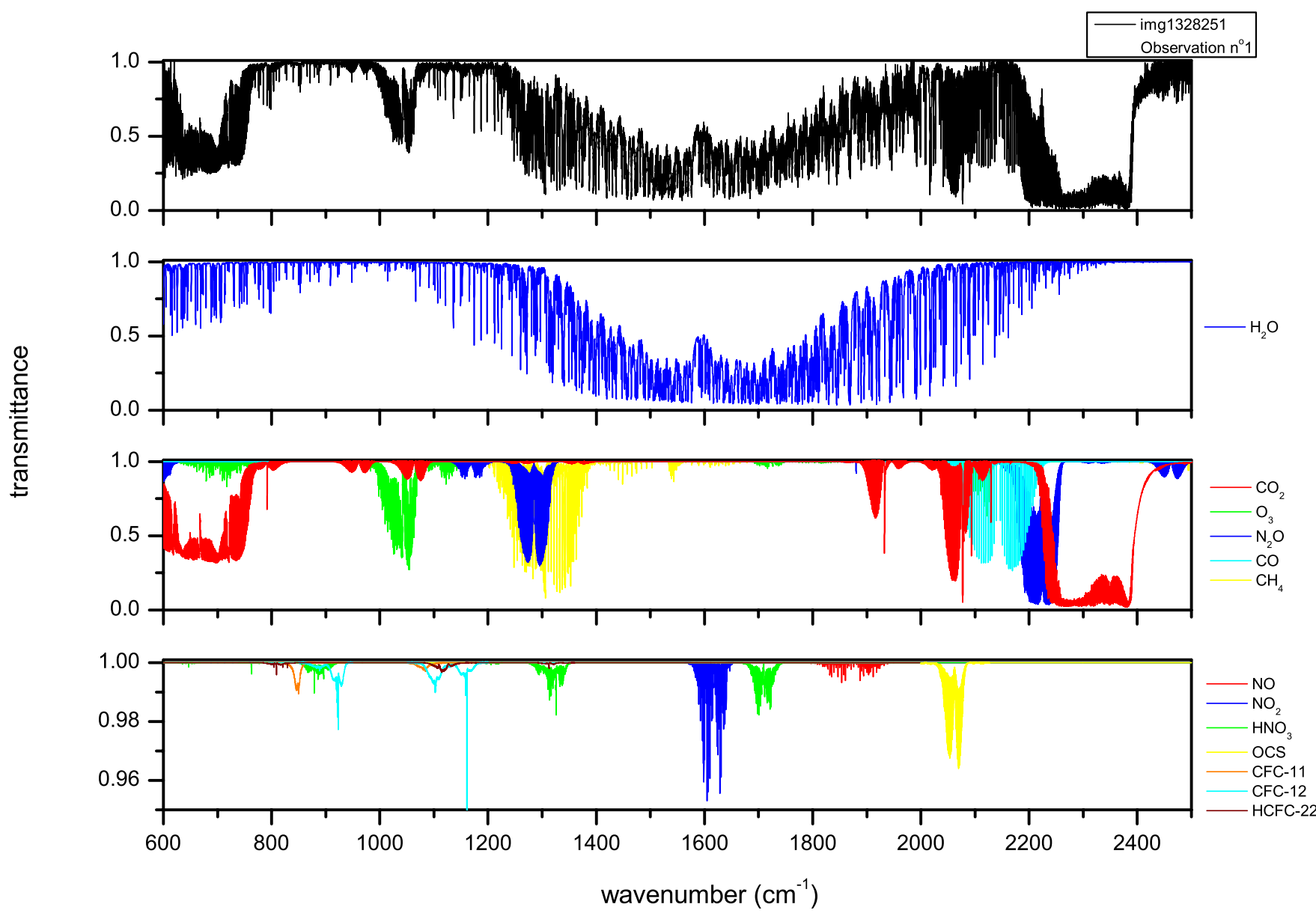

Fig. 1. IMG spectrum (in transmittance units) in the $600-2500 \mathrm{~cm}^{-1}$ spectral range recorded over South Pacific (-75.24, -28.82) on 4 April 1997, 04:00:42 GMT (top). Radiative transfer simulations for absorption contributions due to strong (middle) and weak (bottom) absorbers are also provided.

in Rodgers (2000). These methods rely on a forward radiative transfer model with a spectroscopic database like HITRAN (Rothman et al., 1998) or GEISA (Jaquinet-Husson et al., 1999), and uses a minimization scheme optimized for the instrument and the target geophysical variable to retrieve. Intercomparison experiments were recently organized by the IASI Science Team to compare forward simulations for infrared nadir radiances (Tjemkes et al., 2002). Another exercise which made use of IMG spectra was organized to intercompare the performance of retrieval codes under development for MOPITT, TES, and IASI. The sensitivity of the retrieved $\mathrm{CO}$ total column amount to parameters that may impact the inversion accuracy was investigated (Clerbaux et al., 2002).

From the IMG spectra, three categories of geophysical parameters can be inverted: meteorological variables, aerosols and trace gases. Among the trace gases, one may distinguish climate gases $\left(\mathrm{CO}_{2}, \mathrm{~N}_{2} \mathrm{O}, \mathrm{CH}_{4}, \mathrm{CFC} 11, \mathrm{CFC} 12, \mathrm{HCFC} 22\right)$ and chemical reactive gases -that may also be climate gases-
$\left(\mathrm{O}_{3}, \mathrm{CO}, \mathrm{HNO}_{3}, \mathrm{OCS}, \mathrm{SO}_{2}\right)$. The paper is focused on trace gases retrieval. However, since the uncertainty on the retrieved trace gas contents depends on that of meteorological variables $\left(\mathrm{H}_{2} \mathrm{O}\right.$, temperature profile and surface temperature), and to a lower extend on the aerosol absorption contribution, some information of achievable accuracies are also presented for these variables.

\subsubsection{Meteorological variables}

Several teams have recently published their work on temperature and humidity retrievals either for IASI (Prunet et al., 1998, 2001; Lerner et al., 2002; Aires et al., 2002b) or for IMG (Amato et al., 1999; Lubrano et al., 2000). As can be seen from Fig. 1, $\mathrm{H}_{2} \mathrm{O}$ is the main absorber in the infrared spectral range. Due to the thousands of channels with useful information, a selection has to be performed to maximize the information content at each retrieval level (e.g. Rabier et al., 2002; Aires et al., 2002a; Lerner et al., 2002). These studies have demonstrated that accurate profiles (error lower 
IMG $\mathrm{T}_{\mathrm{S}}$ retrieval (April 1-10, 1997)

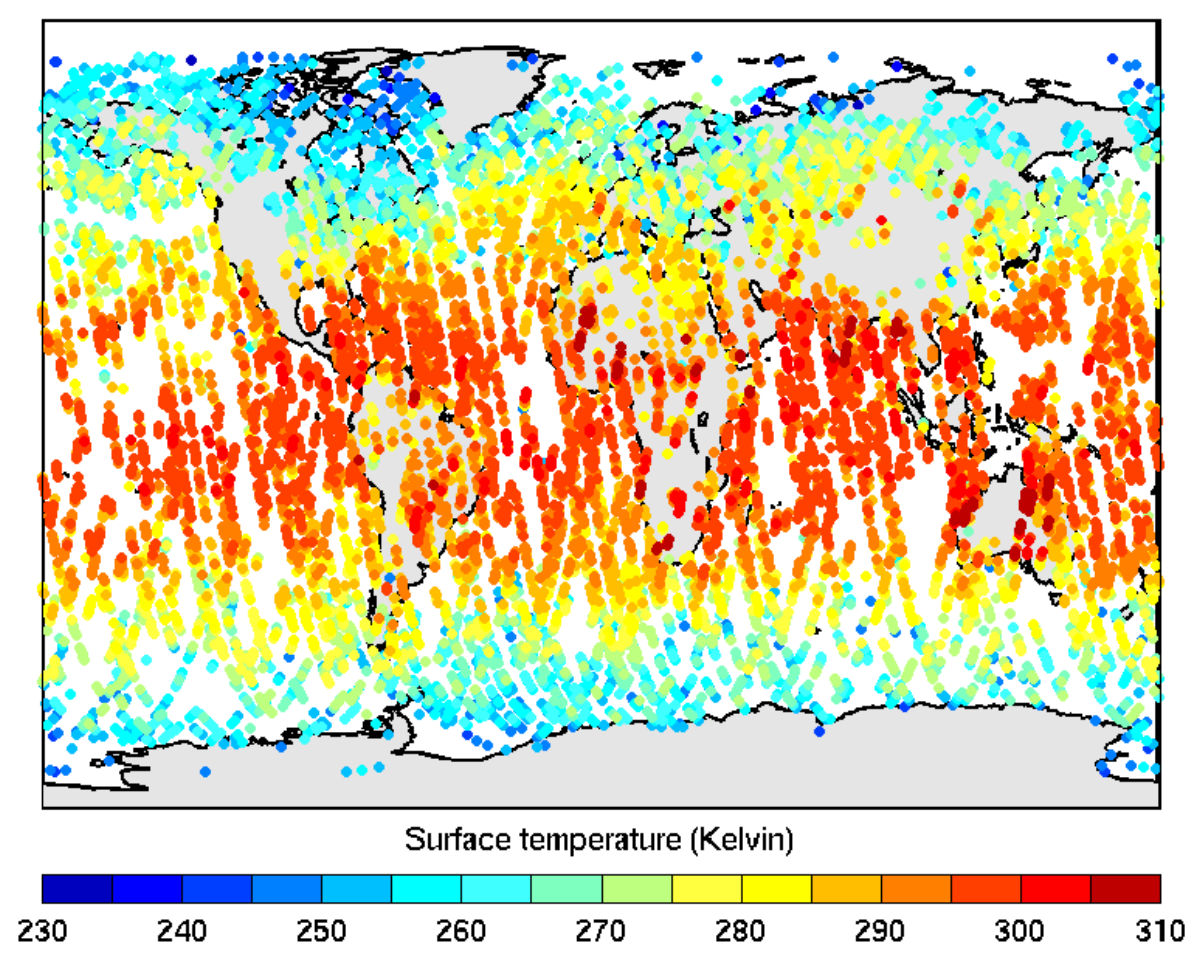

Fig. 2. Surface temperature retrieved from IMG at $976.75 \mathrm{~cm}^{-1}$.

than $10 \%$ in the troposphere) can be obtained. The temperature profiles are measured from the main vibrational bands of $\mathrm{CO}_{2}$ and can be retrieved with accuracies of $1 \mathrm{~K}$ (RMS) at vertical resolution of $1 \mathrm{~km}$, at least in the lower troposphere. Skin surface temperatures (SST) can directly be retrieved from the radiance spectra using atmospheric windows. Figure 2 shows the SST obtained from the IMG measurements for the April period. Temperatures are required as input parameters for the inversion of trace gases.

\subsubsection{Aerosols}

Sensitivity studies performed in the framework of IASI (Kruglanski and De Mazière, 2002) have shown the relative variations in the radiance spectrum that are due to the presence of different populations of aerosols (urban, maritime, volcanic, desert sand). Most of the impact consists of broadband absorption features in the atmospheric window. Sanddust signal in IMG spectra recorded over Sahara were reported in Gribanov et al. (2001) around $1157 \mathrm{~cm}^{-1}$. Further investigations are needed in order to access the potential usefulness of infrared measurements for detection of aerosols events.

\subsubsection{Climate gases}

Climate gases are characterized by their strong absorption contributions within the infrared spectral range making them effective in the process of trapping the longwave radiation escaping to space and hence influencing the Earth radiative budget. In addition to the water vapor contribution, $\mathrm{CO}_{2}$, $\mathrm{N}_{2} \mathrm{O}, \mathrm{CH}_{4}, \mathrm{O}_{3}$, and CFCs are well known to be important contributors to the climate forcing (IPCC, 2001). Although they are responsible for major absorptions in the IMG spectral range (see Fig. 1), inference of their concentrations is difficult due to their low spatial/temporal variability.

Both accuracy and precision are critical parameters for climate research (Keith and Anderson, 2001). For nadir infrared sounders, the accuracy (deviation of the measurement from the true value) is mostly associated with the uncertainty on the spectroscopic parameters, whereas the precision (random error) is mostly associated with the instrumental noise and the assumptions on the atmospheric state during the retrieval process.

For the analysis of long time scale climate observations, accuracy is a critical parameter as it allows Level 1 and Level 2 measurements taken at different times, by different instruments and teams, to be directly compared. Harries et al. (2001) demonstrated that nadir radiance measurements taken by the IRIS instrument in 1970 can be compared with that provided by IMG in 1997, to access the climate forcing due to the increase in greenhouse gases.

For the analysis of local or seasonal short time scales variations, precision is the critical parameter. The potential use of spaceborne remote sensing for the quantitative 
IMG $\mathrm{CH}_{4}$ retrieval (April 1-10, 1997)

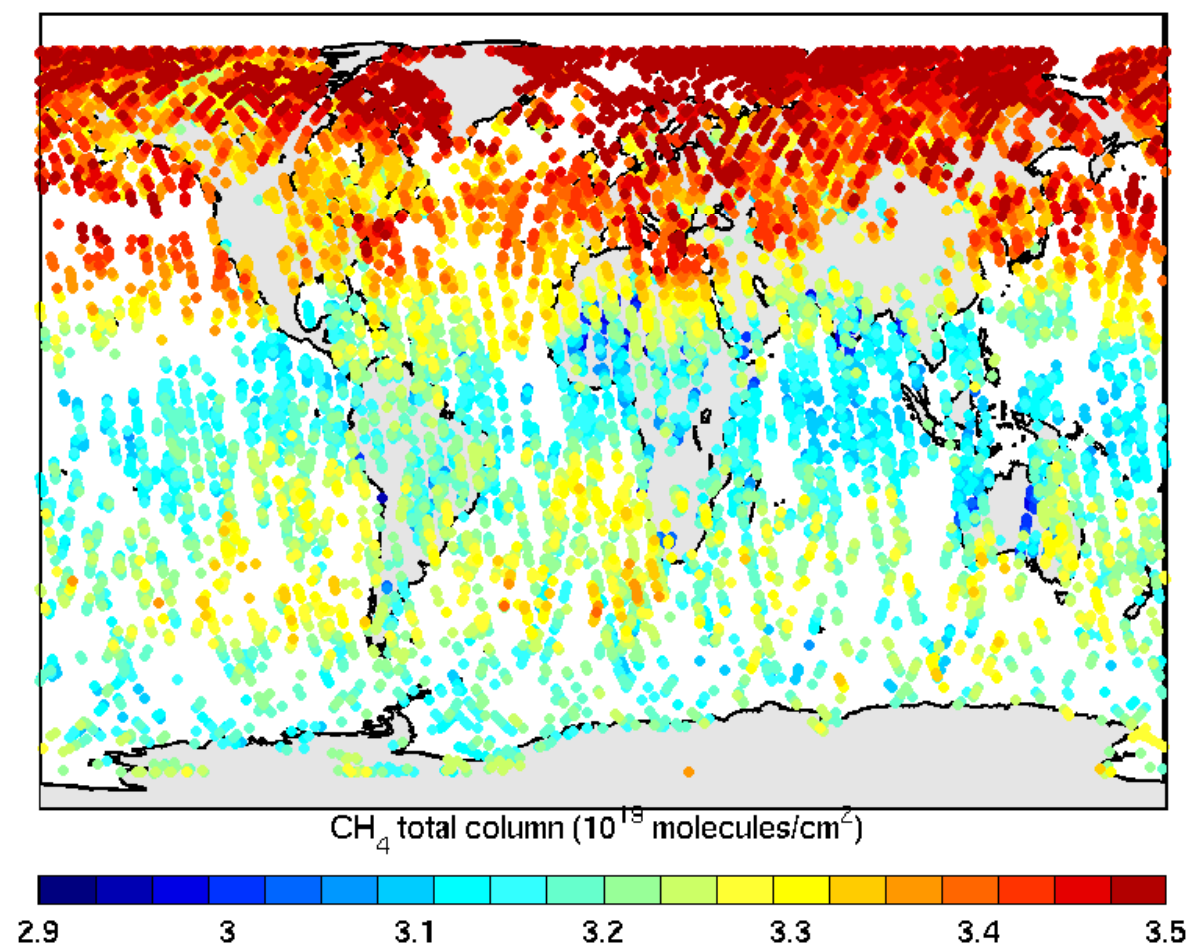

Fig. 3. Methane distribution retrieved from the IMG data.

determination of anthropogenic emissions in the framework of the Kyoto protocol implementation has raised the question as if current or planned instruments could be used. Up to now, very few global distributions measured from space have been reported for climate gases.

\section{$\mathrm{CO}_{2}, \mathrm{~N}_{2} \mathrm{O}$}

Chedin et al. (2002) have shown that annual and seasonal variations can be measured for $\mathrm{CO}_{2}$ and $\mathrm{N}_{2} \mathrm{O}$ from the integrated radiance channels measured by HIRS on the meteorological TIROS-N satellites. Improved high resolution infrared sounders as AIRS and IASI should provide useful information for $\mathrm{CO}_{2}$ if spatial and temporal averaging are performed in order to meet the required precision. For example, Chedin et al. (2003) showed that $1 \%$ uncertainty is achievable for $500 \mathrm{~km} \times 500 \mathrm{~km} / 15$ days spatial and temporal averaging.

\section{$\mathrm{CH}_{4}$}

The direct determination of radiative forcing of methane from infrared nadir radiances has been described in Chazette et al. (1998). New results have recently been obtained for retrieval of $\mathrm{CH}_{4}$ from the IMG spectra for the April period. Total column amounts are represented in Fig. 3.
The distribution is characterized by a strong North-South gradient as expected, with some smaller regional variations. Some errors in the retrieval due to wrong surface emissivity treatment are visible over deserts.

\section{CFC11, CFC12, HCFC22}

Detection of CFC12 has been reported in the IMG spectra by two teams: Lubrano et al. (2002) and Coheur et al. (2003). The latter also showed that large scale averaging allows the detection of CFC11 and HCFC22 for which atmospheric concentration has increased since the control of CFCs emissions. Spatial variabilities can not be seen from their absorption contribution, but they need to be taken into account for a correct representation of ozone which absorbs in the same spectral range.

\subsubsection{Chemical species}

At the beginning of the 1990s, important changes in the trace gases growth rates were reported, and the understanding of these changes in terms of sources and sinks has been the focus of several studies. Large uncertainties remain on the estimated strengths of the sources and sinks of primary trace gases like $\mathrm{CO}$ and $\mathrm{CH}_{4}$, and on the $\mathrm{O}_{3}$ tropospheric budget (WMO, 1999). The oxidation cycles of both $\mathrm{CH}_{4}$ and $\mathrm{CO}$ 

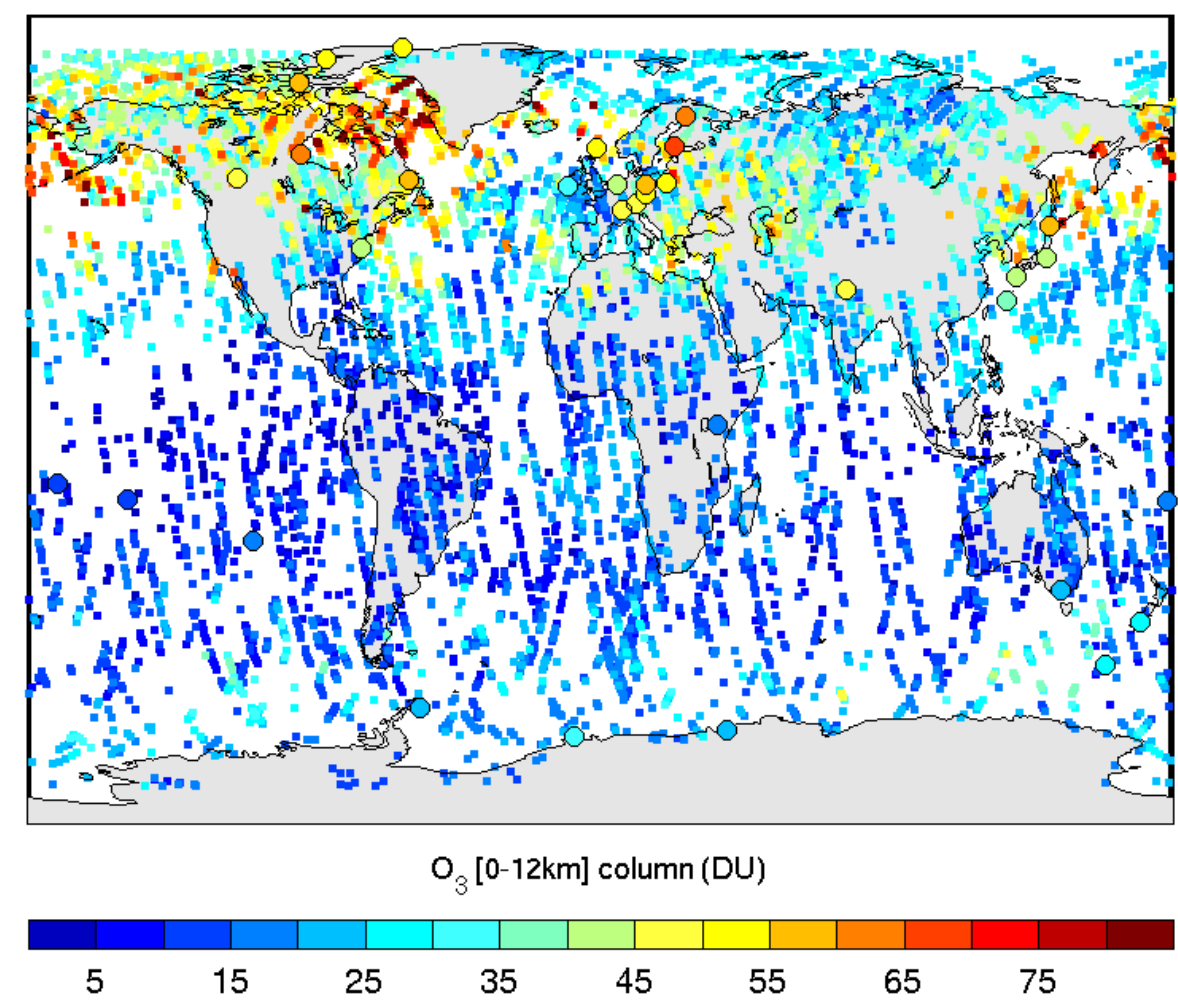

Fig. 4. Partial $\mathrm{O}_{3}(0-12 \mathrm{~km})$ columns distribution retrieved from the IMG data. The corresponding amounts calculated from available averaged ozonesonde profiles in April 1997 are represented by the enlarged colored dots.

either produce or destroy $\mathrm{O}_{3}$ depending on the level of concentration of nitric oxide. Global measurements for these species are required to constrain the oxidizing power of the troposphere and thus infer the global distribution of hydroxyl radical $(\mathrm{OH})$, which is not directly measurable from space. The impact of biomass burning could also be analyzed from these observations.

For these species, radiance channels with relevant information for inversion have to be selected in the IMG spectra. In an ideal situation, these spectral intervals would be located over the strongest absorption band of the molecule and should be sufficiently narrow to exclude the contaminating signal from other gases. A set of spectral channels which minimize interferences has been selected (Clerbaux et al., 1998).

\section{CO}

Global distributions of carbon monoxide total column amounts have been obtained from the IMG spectra using the IASI retrieval algorithm package (Clerbaux et al., 1999; Hadji-Lazaro et al., 1999). Distribution maps and associated uncertainties are provided in Clerbaux et al. (2001). In Clerbaux et al. (2002) the performance of different retrieval codes (MOPITT, TES) on a common IMG dataset are discussed and the main sources of errors on the retrieved columns are identified. The errors in the used temperature profile as well as uncertainty on the instrumental response function are shown to be the main contributions to explain the discrepancies observed in the results provided by the different groups. Other possible causes of errors are uncertainties associated with water vapour, cloud and aerosol loading contents.

Since the failure of IMG, MOPITT has provided an extensive dataset for $\mathrm{CO}$ measurements (Deeter et al., 2003). Current available products were obtained using the thermal-band channels and are provided both on altitude levels and as total column products. The spatial coverage is higher for MOPITT due to its ability to scan across track, whereas IMG is measuring along the track only. The MOPITT uses a broader spectral range, centred on the main $\mathrm{CO}$ aborption lines, whereas the IMG provides high resolution measurements. Both instruments lack sensitivity to the boundary layer and have their maximum sensitivity in the free troposphere.

$\mathbf{O}_{3}$

Total column measurements for ozone using the IASIpackage algorithm are discussed in Turquety et al. (2002). New results were recently obtained for the direct retrieval 


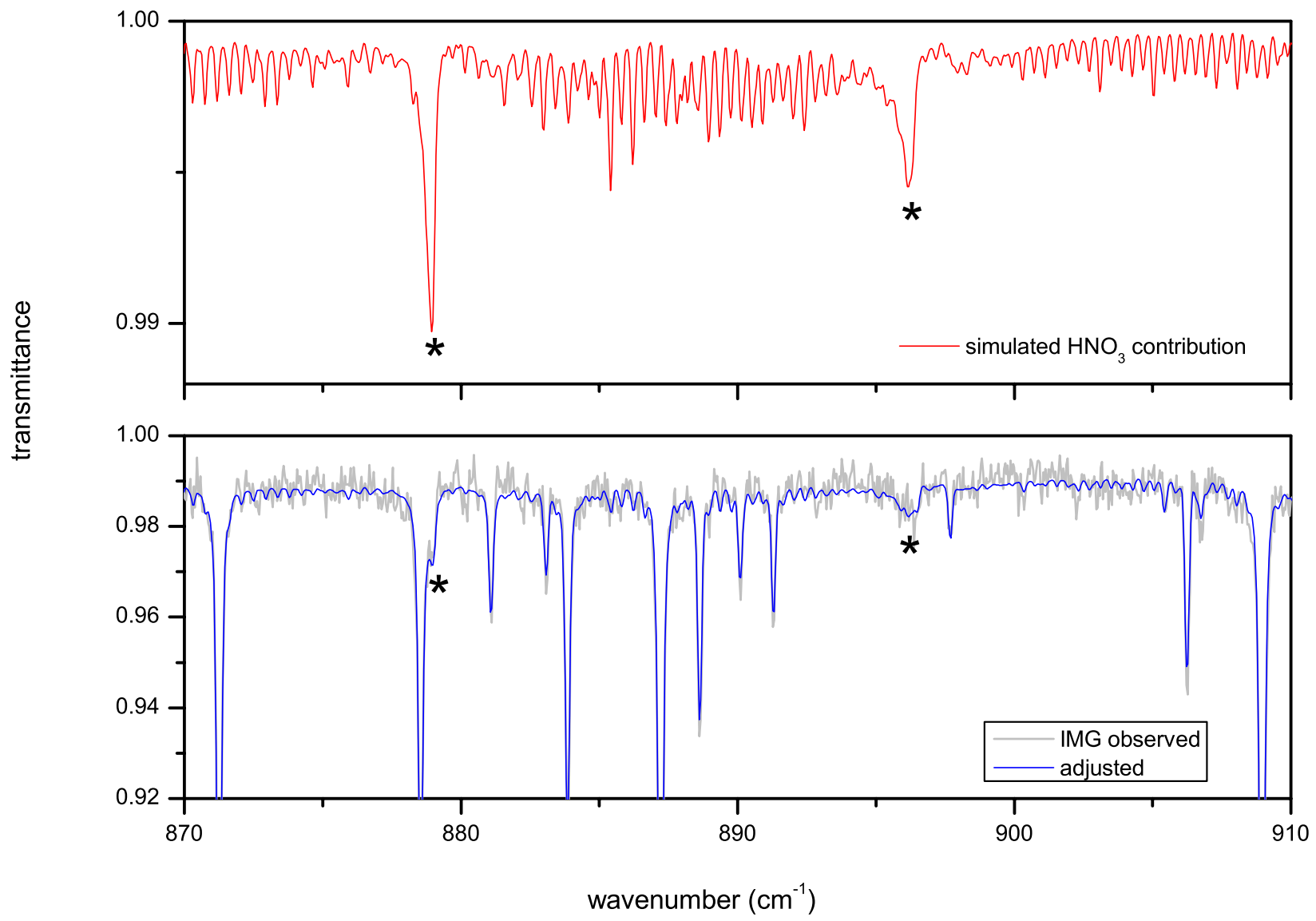

Fig. 5. Detection of $\mathrm{HNO}_{3}$ from IMG data.

of a partial column amount representative of the ozone tropospheric absorption contribution. To overcome the problem of fixing the tropopause height, we have arbitrarily chosen to perform partial column measurements from 0 to $12 \mathrm{~km}$ height. The $(0-12 \mathrm{~km})$ column for ozone derived from the IMG spectra for the April period is represented in Fig. 4. The obtained distribution will be commented in Sect. 4 along with the validation description.

\section{$\mathrm{HNO}_{3}, \mathrm{OCS}, \mathrm{NO}, \mathrm{NO}_{2}, \mathrm{SO}_{2}$}

All these species present small absorption features in the nadir infrared spectrum (see Fig. 1) and their detection is only possible using carefully selected radiance channels. From our current analysis, we have shown that $\mathrm{HNO}_{3}$ and OCS (Payan et al., 1998) can be detected even for unpolluted conditions, as can be seen from Fig. 5 .

Conversely, $\mathrm{NO}$ and $\mathrm{NO}_{2}$ have not been observed yet as their absorption contribution is located in the center of the intense water vapor absorption band. $\mathrm{SO}_{2}$ could be observed under specific volcanoes conditions as recently reported with the AIRS data.

\subsection{Observational requirements for chemistry and climate}

Measurement accuracy requirements to answer the main scientific questions related to atmospheric composition were defined in the framework of an ESA-led study that gathered a consortium of 13 European institutes (Kerridge et al., 2001). The Tables of requirements in the ESA report were provided for accuracy and vertical/horizontal resolutions, and were expressed in both minimum terms (threshold) and most advantageous term (target), defined both for climate and chemistry purposes. In this section, we compare our current guess for measurement uncertainty on the retrieved trace gas total column amounts from nadir IR radiances with these observational requirements. Table 2 provides, for each infrared absorbing molecule, an estimate of its absorption contribution and atmospheric variability, along with the ESA observational requirement and the uncertainty associated with the retrieval (for one pixel/spectrum). The precision achievable from the routine daily measurements (Zander et al., 2002; Barret et al., 2002) performed at the Jungfraujoch station using an similar infrared instrument are also reported for comparison purposes. 
Table 2. Trace gas measurements in the infrared

\begin{tabular}{lccccc}
\hline Constituent & $\begin{array}{c}\text { Infrared } \\
\text { absorption }\end{array}$ & $\begin{array}{c}\text { Atmospheric } \\
\text { variability }\end{array}$ & $\begin{array}{c}\text { Observational } \\
\text { requirement }(\%)\end{array}$ & $\begin{array}{c}\text { Measured } \\
\text { uncertainty (\%) }\end{array}$ & $\begin{array}{c}\text { Jungfraujoch } \\
\text { precision (\%) }\end{array}$ \\
\hline $\mathrm{CO}_{2}$ & high & low & $1 / 4$ & 5 & 2 \\
$\mathrm{~N}_{2} \mathrm{O}$ & high & low & $2 / 5$ & 5 & 2 \\
$\mathrm{CH}_{4}$ & high & medium & $2 / 5$ & 4 & 2 \\
$\mathrm{CFC11}$ & low & low & $10 / 20$ & detected & 8 \\
$\mathrm{CFC12}$ & low & low & $10 / 20$ & detected & 4 \\
$\mathrm{HCFC} 22$ & low & low & $10 / 20$ & detected & 6 \\
$\mathrm{SF}_{6}$ & low & low & - & - & 30 \\
$\mathrm{O}_{3}$ total & high & medium & - & 3 & 5 \\
$\mathrm{O}_{3}$ tropo & high & high & $20 / 30$ & 13 & 8 \\
$\mathrm{CO}$ & high & high & 20 & detected & 8 \\
$\mathrm{OCS}$ & low & medium & - & - & - \\
$\mathrm{SO}_{2}$ & low & high & 20 & detected & 5 \\
$\mathrm{HNO}_{3}$ & low & high & 20 & - & 6 \\
$\mathrm{NO}$ & low & high & $20 / 30$ & - & 10 \\
$\mathrm{NO}_{2}$ & low & high & $20 / 30$ & & - \\
\hline
\end{tabular}

\section{Validation and data assimilation}

Validation is an important step to access the reliability of the measured distributions obtained from the analysis of the 20000 spectra selected from the IMG data. Atmospheric models may be helpful in this framework, along with groundbased or spaceborne measurements. Except for ozone, independent measurements of trace gas concentrations during the IMG activity were sparse, and usually not well co-localized with the data. In this section we summarize the studies undertaken to validate the $\mathrm{O}_{3}$ total column retrievals using TOMS/ADEOS. We show how $\mathrm{O}_{3}(0-12 \mathrm{~km})$ distributions compare with ozonesonde measurements and model calculations, and we demonstrate that indirect validation can be performed using data assimilation.

\section{$4.1 \mathrm{O}_{3}$ total columns}

The ADEOS/TOMS instrument (Krueger and Jaross, 1999) provided high quality, well validated total columns of ozone, allowing a comparison of the IMG total ozone retrievals with a large number of independent data. The co-localized total columns were compared within $\mathrm{a} \pm 0.5^{\circ}$ area, and a $\pm 2 \mathrm{~s}$ time period. After post-processing of the retrieved IMG columns (cloud filter and consistency check), a very good agreement between the two distributions is reached with an rms error $\sim 25 \mathrm{DU}$ and a correlation $\sim 0.9$. The observed differences are mostly explained by the different observation methods used (Turquety et al., 2002).

\section{$4.2 \mathrm{O}_{3}$ tropospheric columns}

Ozonesonde measurements (WOUDC, 2003) have been used in order to validate the partial $\mathrm{O}_{3}$ columns. The IMG re- trievals have been compared to ozonesonde profiles integrated between the surface and $12 \mathrm{~km}$ high. However, it proved to be difficult to find measurements correctly colocalized in space and time. Therefore, a monthly average of the available data has been performed for each measurement site. Figure 4 (enlarged dots) shows the measurements available during the IMG April period. The agreement is globally good, although some discrepancies are observed above Scandinavia, probably due to less accurate IMG retrievals for extremely low surface temperatures.

In order to validate the $(0-12 \mathrm{~km}) \mathrm{O}_{3}$ distributions on a global scale, IMG observations have been compared to predictions from the LMDz/INCA chemistry-transport model (Hauglustaine et al., 2003), for which profiles have been integrated between the surface and $12 \mathrm{~km}$ (see Fig. 6). A direct comparison of the co-localized columns shows that the two distributions are highly correlated $(\mathrm{r}=0.8)$. It also highlights a positive bias between the LMDz/INCA and the IMG columns (mean bias (model-measurement) $\sim 15 \mathrm{DU}$ ). The source of this bias is difficult to identify. It could partly come from the decreasing sensitivity of the IMG instrument in the boundary layer, which could cause an under-estimation of the columns.

\subsection{CO distribution (Level 3)}

Direct validation of CO retrievals from IMG measurements is difficult due to the lack of other CO total column measurements available on a global scale during the same time period. However, routine measurements of $\mathrm{CO}$ surface mixing ratio levels are provided by the NOAA/CMDL network (Novelli et al., 1992). Data assimilation is a powerful tool for analysis of observations provided by instruments that differ 
LMDz/INCA 12km O 3 (April 1-10, 1997)
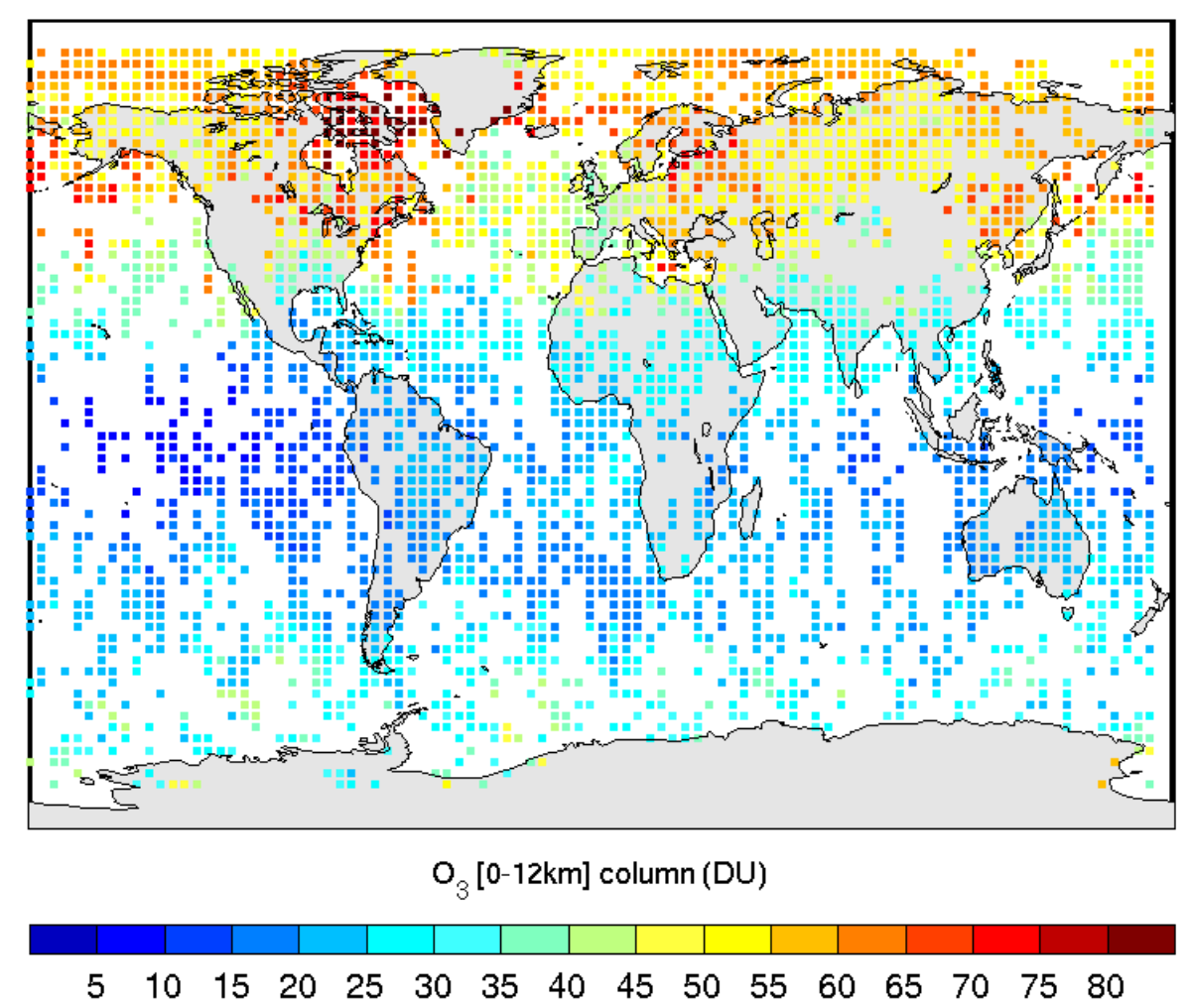

Fig. 6. Ozone (0-12 km) columns, calculated with co-localized profiles provided by LMDz/INCA for 1-10 April 1997.

in nature, resolution, and accuracy, and are distributed irregularly in time and space. This technique also allows an efficient comparison of remotely sensed data with in situ data. A sequential assimilation approach was used to incorporate the CO IMG total column retrieved distributions, along with the associated covariance error matrices, into a global three-dimensional chemistry-transport model (Clerbaux et al., 2001).

The CO surface distributions calculated by the MOZART model (Brasseur et al., 1998; Hauglustaine et al., 1998) were compared to the daily surface mixing ratios available from the NOAA/CMDL network of local stations, for a reference calculation (Fig. 7, no assimilation) and for an assimilation run (Fig. 8, assimilation of CO columns as mesured by IMG). It can be seen that the assimilation of IMG CO data consistently improved the agreement between the model and the CMDL measured data, as all the data above $55 \mathrm{ppbv}$ (17 stations of 22) were found to be in better agreement after assimilation of IMG CO columns in the model.

\section{Conclusions}

As part of the ongoing studies in the framework of the preparation of the IASI mission, we have exploited existing in- formation provided by IMG onbard ADEOS to analyze to which extent monitoring applications requirements could be fulfilled. The study also made use of data provided by other ADEOS sensors, such as POLDER (for cloud filtering) and TOMS (for total ozone validation), in order to improve the quality of the results. The paper details the observational capabilities of IMG for species relevant for atmospheric chemistry or climate studies that are measurable from infrared upwelling radiances. For long-lifetime climate gases such as $\mathrm{CO}_{2}, \mathrm{NO}_{2}$ and CFCs (CFC11, CFC12, HCFC22), large temporal or spatial averaging is required to reach the accuracy requirements. A first global distribution of $\mathrm{CH}_{4}$ from space is reported, showing promising information. Total ozone can be retrieved with a high level of accuracy as was demonstrated using co-located TOMS data. The observational requirements for chemistry are met for tropospheric ozone and CO columns retrieved from IMG. Last but not least, weak infrared absorbing constituents are also detected in the IMG spectra, as for example $\mathrm{HNO}_{3}$.

When compared with ground-based measurements provided by similar Fourier transform infrared instruments, the main strengths of IMG/ADEOS arise from its global Earth coverage sampling capability. As for local measurements, it allows the measurement of several species at the same time 


\section{Reference run}

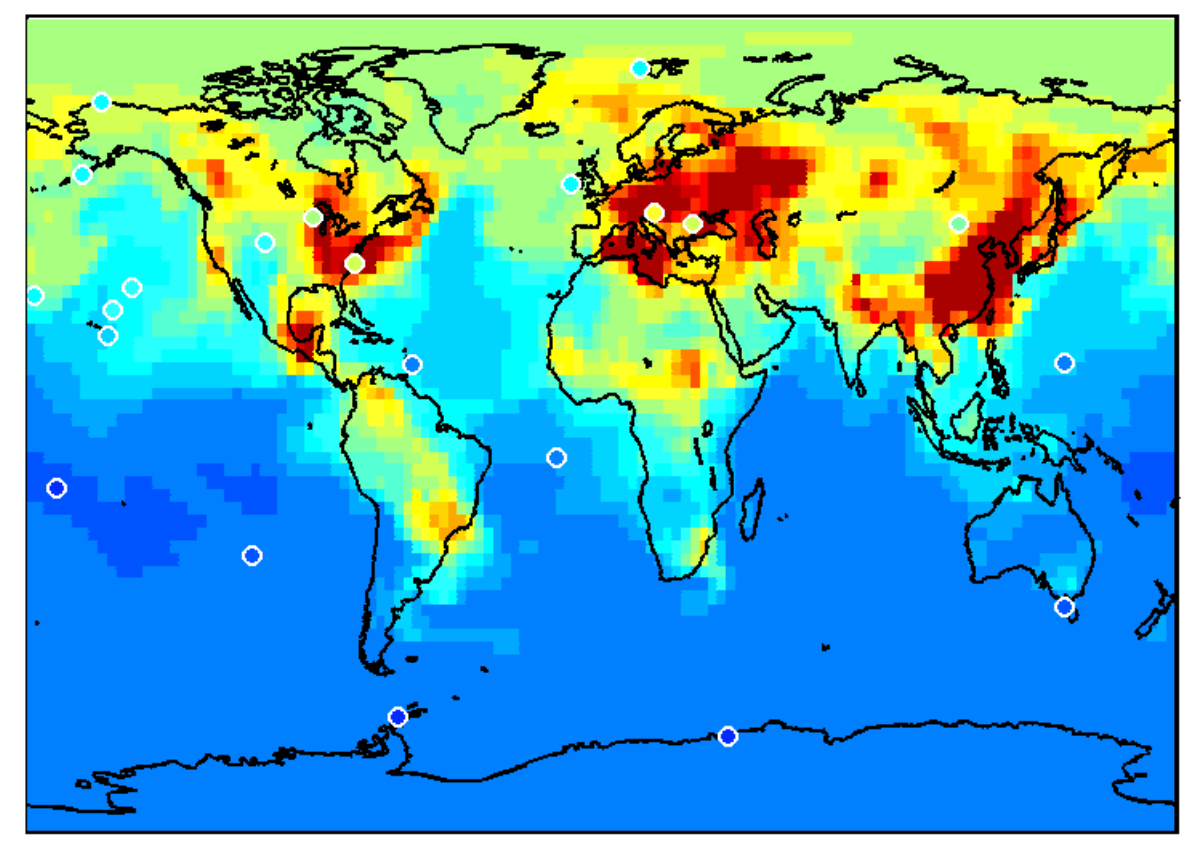

Fig. 7. Surface $\mathrm{CO}$ field for a reference run of the MOZART model. White circled colored data are corresponding colocated averaged mixing ratios measured by the NOAA/CMDL network.

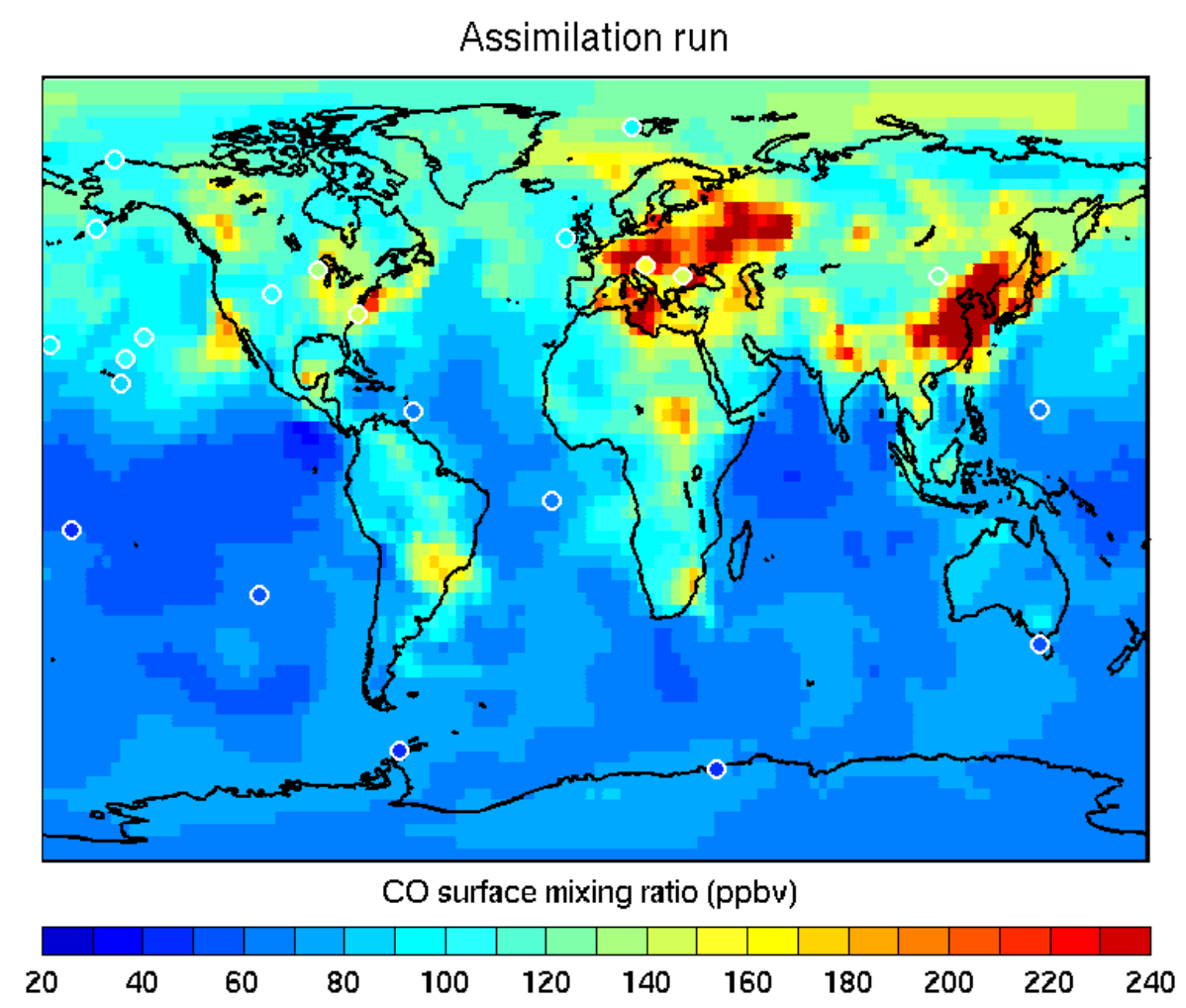

Fig. 8. Surface CO field after sequential assimilation of IMG CO column measurements. White circled colored data are corresponding colocated averaged mixing ratios measured by the NOAA/CMDL network. 
Table 3. Information for instruments quoted in the paper

\begin{tabular}{|c|c|c|c|c|}
\hline Acronym & $\begin{array}{l}\text { Instrument } \\
\text { Web link }\end{array}$ & Platform & Organization & Launch date \\
\hline HIRS & $\begin{array}{l}\text { High resolution Infrared Radiation Sounder } \\
\text { http://daac.gsfc.nasa.gov/CAMPAIGN_DOCS/FTP_SITE/INT_DIS/readmes/t }\end{array}$ & $\begin{array}{l}\text { TOVS } \\
\text { ovs.html }\end{array}$ & NOAA & 1985 \\
\hline GOME & $\begin{array}{l}\text { Global Ozone Monitoring Experiment } \\
\text { http://earth.esa.int/gome }\end{array}$ & ERS2 & ESA & April 1995 \\
\hline IMG & $\begin{array}{l}\text { Interferometric Monitor for Greenhouse gases } \\
\text { http://www.eoc.nasda.go.jp/guide/satellite/sendata/img_e.html }\end{array}$ & ADEOS & NASDA & August 1996 \\
\hline POLDER & $\begin{array}{l}\text { POLarization and Directionality of the Earth's Reflectance } \\
\text { http://www.eoc.nasda.go.jp/guide/satellite/sendata/polder_1_e.html }\end{array}$ & ADEOS & NASDA & August 1996 \\
\hline TOMS & $\begin{array}{l}\text { Total Ozone Mapping Spectrometer } \\
\text { http://www.eoc.nasda.go.jp/guide/satellite/sendata/toms_e.html }\end{array}$ & ADEOS & NASDA & August 1996 \\
\hline MOPITT & $\begin{array}{l}\text { Measurements Of Pollution In The Troposphere } \\
\text { http://terra.nasa.gov/About/MOPITT/about_mopitt.html }\end{array}$ & TERRA & NASA & December 1999 \\
\hline SCIAMACHY & $\begin{array}{l}\text { SCanning Imaging Absorption spectroMeter for Atmospheric CartograpHY } \\
\text { http://envisat.esa.int/instruments/sciamachy/ }\end{array}$ & Envisat & ESA & March 2002 \\
\hline AIRS & $\begin{array}{l}\text { Atmospheric Infrared Sounder } \\
\text { http://www-airs.jpl.nasa.gov/ }\end{array}$ & AQUA & NASA & May 2002 \\
\hline TES & $\begin{array}{l}\text { Tropospheric Emission Spectrometer } \\
\text { http://eos-chem.gsfc.nasa.gov/instruments/tes/introduction.html }\end{array}$ & AURA & NASA & 2004 \\
\hline OMI & $\begin{array}{l}\text { Ozone Monitoring Instrument } \\
\text { http://eos-chem.gsfc.nasa.gov/instruments/omi/introduction.html }\end{array}$ & AURA & NASA & 2004 \\
\hline IASI & $\begin{array}{l}\text { Infrared Atmospheric Sounding Interferometer } \\
\text { http://smsc.cnes.fr/IASI/index.htm }\end{array}$ & Metop & Eumetsat & 2005 \\
\hline GOME2 & $\begin{array}{l}\text { Global Ozone Monitoring Experiment } 2 \\
\text { http://www.esa.int/export/esaME/gome-2.html }\end{array}$ & Metop & Eumetsat & 2005 \\
\hline TROC & TROposheric Chemistry and Climate mission & \multirow{2}{*}{\multicolumn{3}{|c|}{$\begin{array}{l}\text { submitted to ESA/AO for Earth Explorer Opportunity mission } \\
\text { submitted to ESA/AO for Earth Explorer Opportunity mission }\end{array}$}} \\
\hline GEOTROPE & GEOstationary TROpospheric Pollution Explorer mission & & & \\
\hline
\end{tabular}

and location, during day and night, although the uncertainties associated with the retrieved amounts are generally higher, with the notable exception of total ozone. One of the weakness (shared with other passive tropospheric sounders) is due to the viewing geometry that provides a weighted integral of atmospheric properties along the optical path and thus limits the vertical resolution. Furthermore, upwelling radiances show a lack of sensitivity toward the ground, which restricts the capability to sound of the boundary layer. These limitations can in part be alleviated by the use of atmospheric modeling using data assimilation techniques, as shown in the paper. The possibility to retrieve some vertical information (3 or 4 layers) from the IMG high spectral resolution was not investigated at this stage.

Progress in atmospheric sounding from space is expected from satellites encompassing combination of improved instruments using different sounding techniques, and enhanced viewing capabilities. The three atmospheric instruments onboard ENVISAT should bring new information in the next few months. In the forthcoming years, the simultaneous measurements of tropospheric key species $\left(\mathrm{CO}, \mathrm{O}_{3}\right.$, and $\mathrm{NO}_{\mathrm{x}}$ ), as well as improved vertical information for ozone will be possible from the AURA and METOP platforms from the joint measurements provided by OMI and TES, GOME2 and IASI. On a longer term, both ESA and NASA are studying new satellite concepts of combining several atmospheric sounding instruments to meet the observational requirements for atmospheric chemistry. Innovative platforms combining UV-visible and infrared instruments have recently been submitted to ESA for launch on geostationary orbit (GEOTROPE - see Table 3) or on a drifting orbit (TROC - see Table 3). Indeed, the low revisit time (2 times per day for a given location) associated with the polar orbit of the satellite restricts the usefulness for local or regional pollution studies involving fast chemically reactive species.

Integrated approaches combining space-borne measurements with ground-based observations into atmospheric models using data assimilation and inversion sources techniques should dramatically improve our understanding of tropospheric chemistry. For climate gases, the needs are more focused on definition of instruments with improved measurement performances. 
Acknowledgements. The authors are grateful to the IMG team for providing the Level 1 IMG data. Our work has benefit from the scientific contribution of several people which we would like to acknowledge: C. Boonne, C. Camy-Peyret, V. Cassé, P. Chazette, T. Clough, P. Couvert, M. De Mazière, D. Edwards, C. Granier, D. Hauglustaine, D. Hurtmans, B. Khattatov, M. Kruglanski, J.-F. Lamarque, M. Luo, J.-F. Müller, S. Payan, P. Prunet, S. Thiria, J. Wang, and R. Zander. We thank P. Novelli for providing the NOAA/CMDL CO measurements. This work was undertaken in the framework of the ISSWG (IASI Sounding Science Working Group) activities under the auspices of EUMETSAT (European Organization for the Exploitation of Meteorological Satellites) and CNES (Centre National d'Etudes Spatiales).

\section{References}

Abrams, M. C., Chang, A. Y., Gunson, M. R., Abbas, M. M., Goldman, A., Irion, F. W., Michelsen, H. A., Newchurch, M. J., Rinsland, C. P., Stiller, G. P., and Zander, R.: On the assessment and uncertainty of atmospheric trace gas burden measurements with high resolution infrared solar occultation spectra from space by the ATMOS experiment, Geophys. Res. Lett., 23, 2337-2340, 1996.

Aires, F., Rossow, W. B., Scott, N. A., and Chedin, A.: Remote sensing from the infrared atmospheric sounding interferometer: 1. Compression, denoising and first-guess retrieval algorithms, J. Geophys. Res., 107, D22, 4619, 10.1029/2001JD000955, 2002a.

Aires, F., Rossow, W. B., Scott, N. A., and Chedin, A.: Remote sensing from the infrared atmospheric sounding interferometer: 2. Simultaneous retrieval of temperature, water vapor, and ozone atmospheric profiles, J. Geophys. Res., 107, D22, 4620, 10.1029/2001JD001591, 2002b.

Amato, U., Cuomo, V., De Feis, I., Romano, F., Serio, C., and Kobayashi, H.: Inverting for geophysical parameters from IMG radiances, IEEE Trans. on Geosc. and Remote Sens., 37, 16201632, 1999.

Barret, B., De Mazière, M., and Demoulin, M: Retrieval and characterization of ozone profiles from solar infrared spectra at the Jungfraujoch, J. Geophys. Res., 107, 24, 10.1029/2001JD001298, 2002.

Brasseur, G. P., Hauglustaine, D. A., Walters, S., Rasch, P. J., Müller, J.-F., Granier, C., and Tie, X. X.: MOZART, a global chemical transport model for ozone and related chemical tracers, 1, Model description, J. geophys. Res., 103, 28 265-28 289, 1998.

Chahine, M. T.: Inverse problems in radiative transfer: Determination of atmospheric parameters, J. Atmos. Sci., 27, 960-967, 1970.

Chazette, P., Clerbaux, C., and Mégie, E.: Direct estimate of the methane radiative forcing using nadir spectral radiances, Appl. Optics, 37, 3113-3120, 1998.

Chedin, A., Hollingsworth, A., Scott, N. A., Serrar, S., Crevoisier, C., and Armante, R.: Annual and seasonal variations of atmospheric $\mathrm{CO}_{2}, \mathrm{~N}_{2} \mathrm{O}$, and $\mathrm{CO}$ concentrations retrieved from NOAA/TOVS satellite observations, Geophys. Res. Lett., 29, 8, 10.1029/2001GL014082, 2002.

Chedin, A., Hollingsworth, A., Scott, N. A., Saunders, R., Matricardi, M., Etcheto, J., Clerbaux, C., Armante, R., and
Crevoisier, C.: The feasibility of monitoring $\mathrm{CO}_{2}$ from high resolution infrared sounders, J. Geophys. Res., 108, D2, 10.1029/2001JD001443, 2003.

Clerbaux, C., Chazette, P., Hadji-Lazaro, J., Mégie, G., Müller, J.F., and Clough, S. A.: Remote sensing of $\mathrm{CO}, \mathrm{CH}_{4}$, and $\mathrm{O}_{3}$ using a space-borne nadir-viewing interferometer, J. Geophys. Res., 103, D15, 18 999-19013, 1998.

Clerbaux, C., Hadji-Lazaro, J., Payan, S., Camy-Peyret, C., and Mégie, G.: Retrieval of CO columns from IMG/ADEOS spectra, IEEE Trans. Geosci. and Remote Sens., 37, 1657-1661, 1999.

Clerbaux, C., Hadji-Lazaro, J., Hauglustaine, D., Mégie, G., Khattatov, B., and Lamarque, J.-F.: Assimilation of carbon monoxide measured from satellite in a three-dimensional chemistrytransport model, J. Geophys. Res., 106, D14, 15 385-15394, 2001.

Clerbaux, C., Hadji-Lazaro, J., Payan, S., Camy-Peyret, C., Wang, J., Edwards, D., and Luo, M.: Retrieval of CO from nadir remotesensing measurements in the infrared by use of four different inversion algorithms, Appl. Opt., 41, 7068-7078, 2002.

Clough, S. A., Rinsland, C. P., and Brown, P. D.: Retrieval of tropospheric ozone from simulations of nadir spectral radiances as observed from space, J. Geophys. Res., 100, 16 579-16 593, 1995.

Coheur, P.-F., Clerbaux, C., and Colin, R.: Spectroscopic measurements of halocarbons and hydrohalocarbons by satellite-borne remote sensors, J. Geophys. Res, 108, D4, 10.1029/2002JD002649, 2003.

Deeter, M. N., Emmons, L. K., Francis, G. L., Edwards, D. P., Gille, J. C., Warner, J. X., Khattatov, B., Ziskin, D., Lamarque, J.-F., Ho, S.-P., Yudin, V.; Attié, J.-L., Packman, D., Chen, J., Mao, D., Drummond, J. R.: Operational carbon monoxide retrieval algorithm and selected results for the MOPITT instrument, J. Geophys. Res. 108, D14 ,4399, 10.1029/2002JD003186, 2003.

De Mazière, M., Hennen, O., Van Roozendael, M., Demoulin, P., and De Backer, H.: Daily ozone vertical profile model built on geophysical grounds, for column retrieval from atmospheric high-resolution infrared spectra, J. Geophys. Res., 104, D19, 23 855-23 869, 1999.

Gribanov, K. G., Zakharov, V. I., Tashkun, S. A., and Tyuterev, V. G.: A new software tool for radiative transfer calculations and its application to IMG/ADEOS spectra, J. Quant. Spectrosc. Radiat. Transfer, 68, 435-451, 2001.

Hadji-Lazaro, J., Clerbaux, C., and Thiria, S.: An inversion algorithm using neural networks to retrieve atmospheric CO total columns from high-resolution nadir radiances, J. Geophys. Res., 104, D19, 23 841-23 854, 1999.

Hadji-Lazaro, J., Clerbaux, C., Couvert, P., Chazette, P., and Boonne, C.: Cloud filter for CO retrieval from IMG infrared spectra using ECMWF temperatures and POLDER cloud data, Geophys. Res. Lett., 28, 2397-2400, 2001.

Harries, J. E., Brindley, H. E., Sagoo, P. J., and Bantges, R. J.: Increases in greenhouse forcing inferred from the outgoing longwave radiation spectra of the Earth in 1970 and 1997, Nature, 410, 355-357, 2001.

Hauglustaine, D. A., Brasseur, G. P., Walters, S., Rasch, P. J., Müller, J.-F., Emmons, L. K., and Carroll, M. A.: MOZART: a global chemical transport model for ozone and related chemical tracers, 2, Model results and evaluation, J. Geophys. Res., 103, 28 291-28 335, 1998.

Hauglustaine, D., Hourdin, F., Jourdain, L., Filiberti, M.-A., Wal- 
ters, S., and Lamarque, J.-F.: Interactive chemistry in the Laboratoire de Meteorologie Dynamique general circulation model: description and background tropospheric chemistry evaluation, submitted to J. Geophys. Res., 2003.

IPCC - Climate Change 2001: The Scientific Basis, Contribution of working group I to the third assessment report of the Intergouvernmental Panel on Climate Change, edited by J. T. Houghton, Y. Ding, D. J. Griggs, M. Noguer, P. J. van der Linden, X. Dai, K. Maskell, and C. Maskell, Cambridge Univ. Press, 2001.

Jacquinet-Husson, N., Arié, E., Barbe, A., Brown, L. R., Bonnet, B., Camy-Peyret, C., Champion, J. P., Chédin, A., Chursin, A., Clerbaux, C., Duxbury, G., Flaud, J. M., Fourrié, N., Fayt, A., Graner, G., Gamache, R., Goldman, A., Guelachvilli, G., Hartmann, J. M., Hillico, J. C., Lefèvre, G., Naumenko, V., Nemtchinov, V., Nikitin, A., Perrin, A., Reuter, D., Rosenmann, L., Rothman, L. S., Scott, N. A., Selby, J., Sinitsa, L. N., Sirota, J. M., Smith, A., Smith, K., Tyuterev, VI. G., Tipping, G. H., Urban, S., Varanasi, P., and Weber, M.: The 1997 spectroscopic GEISA databank, J. Quant. Spectrosc. Radiat. Transfer, 62, 205-254, 1999.

Keith, D. W. and Anderson, J. G.: Accurate spectrally resolved infrared radiance observation from space: Implications for the detection of decade-to-century-scale climatic change, J. of Climate, 14, 979-990, 2001.

Kerridge B. J., Reburn, W. J., Siddans, R., Smith, D. L., Watts, P. D., Clarmann, T. V., Stiller, G. P., Linden, A., Kellmann, A., Remedios, J. J., Lama, F., Barnett, J. J., Murtagh, D., Stegman, J., Merino, F., Baron, P., Roscoe, H., Hausamann, D., Birk, M., Schreier, F., Schimpf, B., Weele, M. V., Kelder, H., Velthoven, P. V., Gauss, M., Isaksen, I., Hauglustaine, D., Clerbaux, C., and Boucher, O.: Definition of mission objectives and observational requirements for an atmospheric chemistry explorer mission, ESA Contract: 13048/98/NL/GD, Final Report, 2001.

Kobayashi, H., Shimota, A., Kondo, K., Okumura, E., Kameda, Y., Shimoda, H., and Ogawa, T.: Development and evaluation of theinterferometric monitor for greenhouse gases: a highthroughput Fourier-transform infrared radiometer for nadir Earth observation, Appl. Opt., 38, 6801-6807, 1999a.

Kobayashi, H., Shimota, A., Yoshigahara, C., Yoshida, I., Uehara, Y., and Kondo, K.: Satellite-borne high-resolution FTIR for lower atmosphere sounding and its evaluation, IEEE Trans. Geosci. and Remote Sens., 37, 1496-1507, 1999b.

Krueger, A. J. and Jaross, G.: TOMS/ADEOS Instrument Characterization, IEEE Trans. Geosci. and Remote Sens., 37, 15431549, 1999.

Kruglanski, M. and De Mazière, M.: Impact of aerosols on IASI observations, in Space Scientific Research in Belgium, 3, Part 3, OSTC (Ed.), 89-95, 2002.

Lerner, J. A., Weisz, E., and Kirchengast, G.: Temperature and humidity retrieval from simulated Infrared Atmospheric Sounding Interferometer (IASI) measurements, J. Geophys. Res., 107, D14, 10.1029/2001JD900254, 2002.

Lubrano, A. M., Serio, C., Clough, S. A., and Kobayashi, H.: Simultaneous inversion for temperature and water vapor from IMG radiances, Geophys. Res. Lett, 27, 2533-2536, 2000.

Lubrano, A. M., Masiello, G., Serio, C., Matricardi, M., and Rizzi, R.: IMG evidence of chlorofluorocarbon absorption in the atmospheric window region $800-900 \mathrm{~cm}^{-1}$, J. Quant. Spectrosc. and Radiat. Transfer, 72, 623-635, 2002.

Luo, M., Beer, R., Jacob, D. J., Logan, J. A., and Rodgers, C. D.:
Simulated observation of tropospheric ozone and CO with the Tropospheric Emission Spectrometer (TES) satellite instrument, J. Geophys. Res., 107, D15, 10.1029/2001JD000804, 2002.

Masiello, G., Serio, C., and Shimoda, H.: Qualifying IMG tropical spectra for clear sky, J. Quant. Spectrosc. Radiat. Transfer, 77, 131-148, 2003.

Novelli, P. C., Steele, L. P., and Tans, P. P.: Mixing ratios of carbon monoxide in the troposphere, J. Geophys. Res., 97, 20731$20750,1992$.

Payan, S., Camy-Peyret, C., and Jaseck, P.: IMG instrument spectral response function and retrieval of $\mathrm{CO}$ and OCS, 8th International Workshop on Atmospheric Science from Space using Fourier Transform Spectrometry (ASSFTS), MeteoFrance, Toulouse, 1998.

Prunet, P., Thepaut, J.-N., and Cassé, V.: Information content of clear sky IASI radiances and their potential for NWP, Q. J. R. Meteorol. Soc., 124, 211-241, 1998.

Prunet, P., Cassé, V., and Thepaut, J.-N.: Infrared atmospheric sounding interferometer data information content: instrument characterization and the impact of a priori information, Tellus, 53A, 2001.

Rabier, F., Fourrié, N., Chafai, D., and Prunet, P.: Channel selection methods for Infrared Atmospheric Sounding Interferometer radiances, Q. J. R. Meteorol. Soc., 128, 1011-1027, 2002.

Rodgers, C. D.: Inverse methods for atmospheric sounding: Theory and practice Series on Atmospheric, Oceanic and Planetary physics, 2, World Scientific, 2000.

Rothman, L. S, Rindsland, C. P., Golman, A., Massie, S. T., Edwards, D. P., Flaud, J.-M., Perrin, A., Camy-Peyret, C., Dana, V., Mandin, J.-Y., Schroeder, J., McCann, A., Gamache, R. R., Wattson, R. B., Yoshino, K., Chance, K. V., Jucks, K. W., Brown, L. R., Nemtchinov, V., and Varanasi, P.: The HITRAN molecular spectroscopic database and HAWKS: 1996 edition, J. Quant. Spectrosc. Radiat. Transfer, 60, 665-710, 1998.

Smith, W. L., Woolf, H. M., and Revercomb, H. E.: Linear simultaneous solution for temperature and absorbing constituent profiles from radiance spectra, Appl. Opt., 30, 1117-1123, 1991.

Té, Y., Jeseck, P., Camy-Peyret, C., Payan, S., Perron, G., and Augustin, G.: Balloonborne calibrated spectroradiometer for atmospheric nadir sounding, Appl. Optics, 41, 6431-6441, 2002.

Tjemkes, S. A., Patterson, T., Rizzi, R., Shephard, M. W., Clough, S. A., Matricardi, M., Haigh, J., Höpfner, M., Payan, S., Trotsenko, A., Scott, N., Rayer, P., Taylor, J., Clerbaux, C., Strow, L. L., DeSouza-Machado, S., Tobin, D., and Knuteson, R.: The ISSWG line-by-line inter-comparison experiment, 77, 433-453, 2002.

Turquety, S., Hadji-Lazaro, J., and Clerbaux, C.: First satellite ozone distributions retrieved from nadir high-resolution infrared spectra, Geophys. Res. Lett., 29, 10.1029/2002GL016431, 2002.

Wetzel, G., Fisher, H., and Oelhaf, H.: Remote sensing of trace gases in the midinfrared spectral region from a nadir view, Appl. Opt., 34, 467-479, 1995.

Worden, H., Beer, R., and Rinsland, C. R.: Airborne infrared spectroscopy of 1994 western wildfires, J. Geophys. Res., 102, D1, 1287-1299, 1997.

World Meteorological Organization (WMO): Global Ozone Research and Monitoring Project, Scientific assessment of ozone depletion: 1998, Rep. 44, Geneva, 1999.

WOUDC: $\mathrm{O}_{3}$ sondes data from the World Ozone and Ultraviolet Ra- 
diation Data Centre (WOUDC), http://www.msc-smc.ec.gc.ca/ woudc/data/index_e.html.

Zander, R., Mahieu, E., Servais, C., Roland, G., Duchatelet, P., Demoulin, P., Delbouille, L., Rinsland, C. P., De Mazière, M., and Blomme, R.: Potential the NDSC in support of the Kyoto Protocol: Examples from the station Jungfraujoch, Switzerland, in Proceedings of "The Third International Symposium on Non$\mathrm{CO}_{2}$ Greenhouse Gases: Scientific Understanding, Control Options and Policy Aspects", Maastricht, The Netherlands, 21-23 January 2002, J. Van Ham et al. (Eds), Millpress-Rotterdam Publishers, ISBN 77017-70-4, 305-310, 2002. 